\title{
Investigation of the cardioprotective effects of Crataegus oxycantha and its molecular mechanism
}

\author{
Harshul Parikh PhD ${ }^{1}$, CB Tripathi MD², Prakash Shah PhD ${ }^{1}$, Vijay Ghori M Pharm¹, Ramesh K Goyal PhD ${ }^{3}$
}

\begin{abstract}
H Parikh, CB Tripathi, P Shah, V Ghori, RK Goyal. Investigation of the cardioprotective effects of Crataegus oxycantha and its molecular mechanism. Curr Res Cardiol 2015;2(4):161-167.
\end{abstract}

BACKGROUND: Crataegus oxycantha has been used as a cardiotonic for the treatment of early stage congestive heart failure; however, there are few authentic investigational studies addressing its cardioprotective use. OBJECTIVE: To investigate the cardioprotective effect of $\mathrm{C}$ oxycantha and to elucidate its possible mechanism of action.

METHODS: The effects of C oxycantha was studied using a rat model of isoproterenol (ISO) $(100 \mathrm{mg} / \mathrm{kg}$ subcutaneous for two days) -induced myocardial necrosis. Cardiac damage was assessed using various biochemical enzymes and histological studies. Various oxidative parameters and $\mathrm{Na}^{+}-\mathrm{K}^{+}$ ATPase activity were studied to elucidate the mechanism of action.

RESULTS: Pretreatment with $\mathrm{C}$ oxycantha significantly prevented the increase in serum levels of cardiac troponin-I, creatine kinase-MB, lactate dehydrogenase, glutamate oxalotransaminase, glutamate pyruvate trans- aminase and uric acid in ISO-treated $(100 \mathrm{mg} / \mathrm{kg})$ rats. The increased serum levels of cholesterol, triglyceride, low-density lipoprotein cholesterol and atherogenic index after ISO administration were decreased to nearly normal levels by $\mathrm{C}$ oxycantha extract. Pretreatment with $\mathrm{C}$ oxycantha in ISOtreated animals produced significant decrease in lipid peroxidation and significant increase in endogenous antioxidant superoxide dismutase, catalase and reduced glutathione in myocardial tissue. C oxycantha extract significantly inhibited $\mathrm{Na}^{+}-\mathrm{K}^{+}$ATPase enzyme present in heart homogenate by virtue of presence of ursolic acid as evidenced by high-performance thin layer chromatography analysis of $\mathrm{C}$ oxycantha extract, which may be a possible mechanism of cardiotonic activity of $\mathrm{C}$ oxycantha.

CONCLUSION: C oxycantha may be viewed as potentially cardiotonic, cardioprotective and antioxidant.

Key Words: Cardiotonic; Cardiac troponin-I; Na+-K+ ATPase; Uric acid

myocardium blood supply (2). C oxycantha extract is traditionally used as a cardiotonic in China, India and many European countries; however, to date, very few authentic investigational studies addressing its cardioprotective use have been performed. Although C oxycantha has been shown to improve cardiac function, the exact mechanism of action remains unclear. cal syndrome arising when delivery of oxygen to the metabolizing tissue is impaired because of decreased contractility of heart muscles, particularly the left ventricle (LV). The syndrome is characterized by breathlessness, exercise intolerance and edema. Left ventricular myocardial damage is commonly caused by hypertension and coronary artery disease, usually myocardial infarction. LV dysfunction produces activation of cardiac and peripheral neurohormonal mechanisms that promote fluid retention. Untreated patients with heart failure demonstrate chronic, sustained, neurohormonal activation and show progressive enlargement of the LV with an associated decline in systolic function. However, these neurohormonal pathways are initially compensatory and beneficial, but eventually they are deleterious. In patients with $\mathrm{CHF}$, improvement in myocardial contractility and LV function is the fundamental treatment for survival. Despite the availablity of treatments, including diuretics, digitalis, vasodilators and angiotensinconverting enzyme inhibitors, the morbidity and mortality risks of CHF remain high.

Digoxin has been the drug of choice for the treatment of CHF due to its positive inotropic effect. The adverse effects of digoxin are cardiac and extracardiac, which include cardiac slowing, reduced conduction through atrioventricular (AV) node, bigeminy, paroxysmal atrial tachycardia, ventricular arrhythmias, hypokalemia, nausea, vomiting and diarrhea. It also possesses a very low therapeutic index; therefore, extreme medical care is needed when a patient is receiving treatment. Crataegus oxycantha is another such plant that has been described by many pharmacopoeias. C oxycantha extract has been traditionally used to treat the early stages of CHF and angina pectoris (1). It has been reported that $\mathrm{C}$ oxycantha may increase the

\begin{abstract}
Animals
All experiments in the present study were performed on healthy adult Wistar rats of either sex (weight $250 \mathrm{~g}$ to $300 \mathrm{~g}$ ), obtained from in house animal breeding. They were housed in polypropylene cages lined with husk, renewed every $24 \mathrm{~h}$ under 12:12 h light dark cycle. They were kept in a temperature-controlled $\left(25^{\circ} \mathrm{C}\right)$ facility and had ad libitum access to food and water. During the experimental period, the animals were fed with standard laboratory diet (Pranav agro industries Ltd, Maharashtra, India).

All experiments and protocols described in the present study were approved by the Institutional Animal Ethics Committee (IAEC) of Government Medical College, Bhavnagar vide permission letter no. IAEC no. 10/2009, amendment no. 02/2011 dated September 13, 2011, and were performed according to the guidelines of Committee for the Purpose of Control and Supervision of Experiments on Animals, ministry of social justice and empowerment, government of India, New Delhi.
\end{abstract}

\begin{abstract}
METHODS
Materials

Isoproterenol (ISO) and digoxin were purchased from Sigma-Aldrich. C oxycantha mother tincture of SBL Homeopathic, Delhi was purchased and used for the present study. All reagents and chemicals used in the present study were of analytical grade. Standard enzymatic kits for estimation of serum parameters were commercially purchased. Albino Wistar rats were purchased from Cadila Pharmaceuticals, Dholka, India.
\end{abstract}

${ }^{1}$ Shantilal Shah Pharmacy College, MK Bhavnagar University; ${ }^{2}$ Government Medical College, Department of Pharmacology, Bhavnagar; ${ }^{3}$ VClinBio Labs, Shri Ramachandra University, Chennai, India

Correspondence: Dr Harshul Parikh, Shantilal Shah Pharmacy College, MK Bhavnagar University, Sardar Vallabhbhai Patel Campus, Gaurishanker Lake Road, Bhavnagar, 364002 India.E-mail harshul72@yahoo.com, harshulparikh@gmail.com 


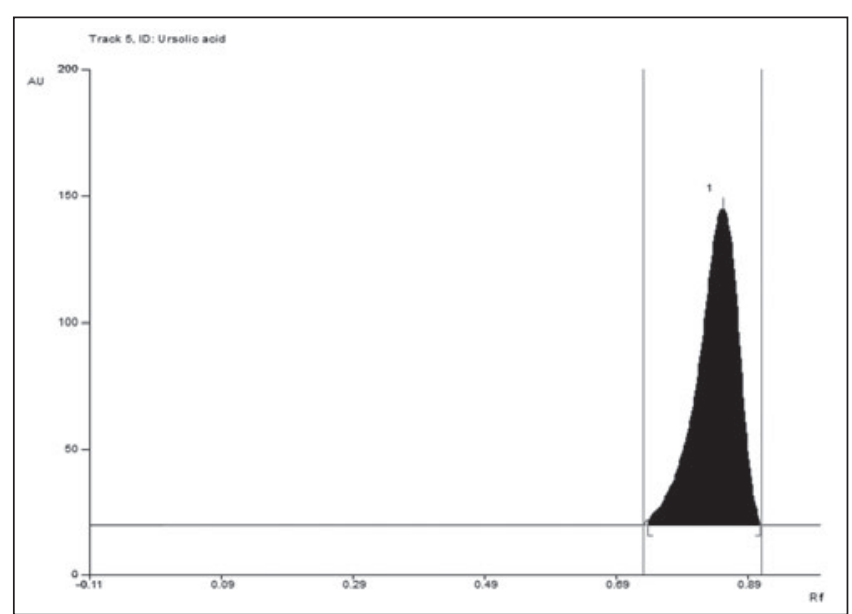

Figure 1) High-performance thin layer chromatography scanned chromatogram of standard ursolic acid

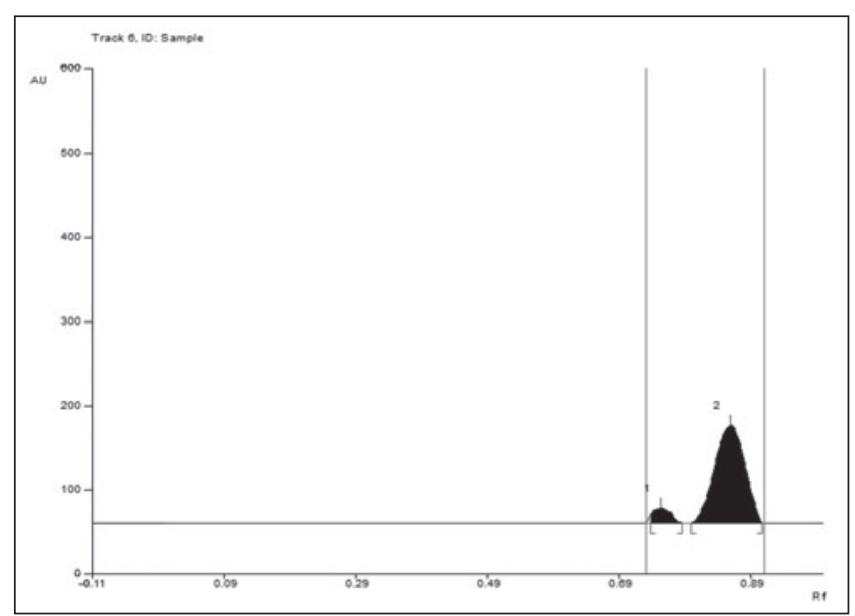

Figure 2) High-performance thin layer chromatography scanned chromatogram of Crataegus oxycantha extract

Phytochemical analysis of C oxycantha extract

Total phenolic content and total flavonoid content were determined using an ultraviolet (UV) spectroscopic method (3). In vitro antioxidant activity of the plant was determined using 1,1-Diphenyl-2picrylhydrazyl (DPPH) assay and UV spectrophotometry as described by Mensor et al (4). High-performance thin layer chromatography (HPTLC) of $\mathrm{C}$ oxycantha extract was performed on preactivated $\left(100^{\circ} \mathrm{C}\right)$ silica gel $60 \mathrm{~F}_{254}$ HPTLC plates $(10 \mathrm{~cm} \times 10 \mathrm{~cm} ; 0.25 \mathrm{~mm}$ layer thickness). The CAMAG densitometry (CAMAG Model-3 TLC scanner equipped with Camag CATS 4 software), a reflectance spectrometer of monitoring range $190 \mathrm{~nm}$ to $700 \mathrm{~nm}$ was used for the analysis.

Standardization of C oxycantha dose

A pilot study was performed to establish the optimum dose of $\mathrm{C}$ oxycantha that exhibited maximum cardioprotective effect during the 30-day treatment period. It was found that $25 \mathrm{mg} / \mathrm{kg} / \mathrm{day}$ and $50 \mathrm{mg} / \mathrm{kg} / \mathrm{day}$ doses of $\mathrm{C}$ oxycantha were more effective in functional recovery of biochemical alterations, and were selected for further evaluation in the present study.

\section{Experimental design}

The effect of $\mathrm{C}$ oxycantha was studied using an ISO-induced myocardial necrosis rat model. Albino Wistar rats were subcutaneously injected with ISO $100 \mathrm{mg} / \mathrm{kg}$ on two consecutive days at an interval of $24 \mathrm{~h}$ to induce myocardial toxicity. The animals were randomly assigned to five groups as follows. Group I (normal control) animals
TABLE 1

Total phenolic and flavonoid content of Crataegus oxycantha

Total phenolic content

Total flavonoid content

Free radical inhibition activity

75.2 mg Gallic acid equivalents/g dry weight 76 mg Rutin equivalents/g dry weight $62.04 \%$

TABLE 2

Effect of Crataegus oxycantha extract on body weight (BW), heart weight (HW) and HW/BW ratio

\begin{tabular}{lccc}
\hline Group & BW, g & HW, g & $\begin{array}{c}\text { HW/BW } \\
\text { ratio }\end{array}$ \\
\hline Control & $288.3 \pm 6.15$ & $0.69 \pm 0.004$ & 0.0024 \\
$\begin{array}{l}\text { Control + C oxycantha }(50 \mathrm{mg} / \mathrm{kg} \\
\text { body weight orally) }\end{array}$ & $274.2 \pm 4.36$ & $0.68 \pm 0.004$ & 0.0025 \\
ISO $(100 \mathrm{mg} / \mathrm{kg})$ & & & \\
ISO $(100 \mathrm{mg} / \mathrm{kg}+$ C oxycantha & $223.3 \pm 5.43^{\star}$ & $0.93 \pm 0.005^{\star}$ & $0.0042^{\star}$ \\
$\quad 25 \mathrm{mg} / \mathrm{kg}$ body weight orally) & & & \\
ISO $(100 \mathrm{mg} / \mathrm{kg}+$ C oxycantha & $279.2 \pm 3.52^{\dagger \ddagger}$ & $0.70 \pm 0.012^{\dagger \ddagger}$ & $0.0025^{\dagger \ddagger}$ \\
$50 \mathrm{mg} / \mathrm{kg}$ body weight orally) & & &
\end{tabular}

Data presented as mean $\pm S D$ unless otherwise indicated. *Significantly different from control $(P<0.05)$; 'Significantly different from isoproteronol (ISO)-

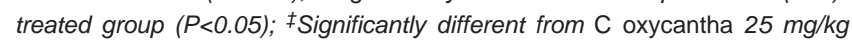
$(P<0.05)$

received normal food and water ad libitum everyday for 30 days and injected $0.9 \% \mathrm{w} / \mathrm{v}$ normal saline for two consecutive days at an interval of $24 \mathrm{~h}$. Group II (diseased control) animals received ISO $100 \mathrm{mg} /$ $\mathrm{kg}$ was subcutaneously injected for two consecutive days at an interval of 24 h. Group III (Normal control + C oxycantha extract) animals received $\mathrm{C}$ oxycantha extract $50 \mathrm{mg} / \mathrm{kg} /$ day orally administered for 30 days. Group IV (diseased control $+\mathrm{C}$ oxycantha extract $25 \mathrm{mg} / \mathrm{kg}$ ) animals subcutaneously injected ISO $100 \mathrm{mg} / \mathrm{kg}$ for two consecutive days at an interval of $24 \mathrm{~h}$ after oral pretreatment with $\mathrm{C}$ oxycantha extract $25 \mathrm{mg} / \mathrm{kg} /$ day for 30 days. Group V (diseased control + C oxycantha extract $50 \mathrm{mg} / \mathrm{kg}$ ) animals subcutaneously injected with ISO $100 \mathrm{mg} / \mathrm{kg}$ for two consecutive days at an interval of $24 \mathrm{~h}$ after oral pretreatment with $\mathrm{C}$ oxycantha extract $50 \mathrm{mg} / \mathrm{kg} /$ day for 30 days.

Collection of blood samples and separation of serum

Blood samples were drawn from the retroorbital plexus under light ether anesthesia without anticoagulant at day 30 of treatment. The serum was separated and used for biochemical analysis. In vitro quantitative measurement of serum cardiac troponin-I (cTnI) was performed using the Tosoh AIA system analyzer, which was based on an immunofluorescent assay. Serum CK-MB, LDH, SGOT, SGPT, uric acid, total cholesterol, triglyceride and high-density lipoprotein (HDL) cholesterol were estimated using commercially available standard biochemical kits. Low-density lipoprotein (LDL) cholesterol and atherogenic index were determined using a standard formula.

\section{Estimation of fecal cholesterol}

Lipids were extracted from feces by the procedure developed by Folch et al (5). Briefly, the fecal matter solution $(20 \% \mathrm{w} / \mathrm{v})$ was prepared in a chloroform:methanol $(2: 1)$ mixture. The lipids were extracted by mixing 1 volume of fecal matter solution with 4 volumes of chloroformmethanol mixture. It was then vortexed and centrifuged at $3000 \mathrm{rpm}$ for $5 \mathrm{~min}$. The lower organic phase containing lipids was transferred to another tube and the extraction procedure was repeated. To this solution, $0.2 \mathrm{~mL}$ of magnesium chloride $(0.017 \%)$ per $\mathrm{mL}$ of organic extract was added, vortexed and centrifuged. The lower phase was transferred and evaporated. The dried lipid residues were dissolved in solution of $0.1 \%$ Triton X-100 in chloroform. The resultant solution was then evaporated to dryness and dried residue was used to estimate total cholesterol. 
TABLE 3

Effect of Crataegus oxycantha on serum levels of cardiac troponin-I (cTN-I), creatine kinase-MB (CK-MB) and lactate dehydrogenase (LDH)

\begin{tabular}{lccl} 
Groups & CTN-I, IU/L & CK-MB, IU/L & LDH, IU/L \\
\hline Control & 0.02 & $610.5 \pm 27.36$ & $172.3 \pm 15.00$ \\
$\begin{array}{l}\text { Control + C oxycantha } 50 \mathrm{mg} / \mathrm{kg} \\
\text { body weight orally }\end{array}$ & 0.02 & $560.4 \pm 12.08$ & $174.6 \pm 7.54$ \\
ISO $(100 \mathrm{mg} / \mathrm{kg})$ & & & \\
ISO $(100 \mathrm{mg} / \mathrm{kg}+$ C oxycantha & $0.037 \pm 0.02^{\dagger}$ & $684.5 \pm 10.84^{\dagger}$ & $233.8 \pm 12.00^{\dagger}$ \\
$\quad 25 \mathrm{mg} / \mathrm{kg}$ body weight orally) & & & \\
$\begin{array}{l}\text { ISO }(100 \mathrm{mg} / \mathrm{kg}+\text { C oxycantha } \\
50 \mathrm{mg} / \mathrm{kg} \text { body weight orally) }\end{array}$ & $0.02^{\dagger}$ & $590.8 \pm 14.92^{\dagger \ddagger}$ & $198.2 \pm 9.28^{\dagger}$ \\
\hline
\end{tabular}

Data presented as mean $\pm S D$ unless otherwise indicated. *Significantly different from control $(P<0.05)$; ${ }^{\dagger}$ Significantly different from isoproteronol (ISO)-treated group ( $P<0.05)$; ₹Significantly different from C oxycantha $25 \mathrm{mg} / \mathrm{kg}(P<0.05)$

\section{Collection of cardiac tissue}

Rats were euthanized and the hearts were dissected after collection of serum. The dissected hearts were used for tissue biochemical analysis and histopathological study. Lipid peroxidation (LPO) in terms of malondialdehyde and superoxide dismutase (SOD) were estimated using the method described by Slater and Sawyer (6), and Mishra and Fridovich (7), respectively. Levels of reduced glutathione (GSH) were estimated according to the method of Moran et al (8). Catalase was estimated according to the method described by Hugo (9). $\mathrm{Na}^{+}-\mathrm{K}^{+}$-ATPase activity was assayed according to the method described by Bonting (10).

Histological examination was performed on myocardial tissue. Briefly, blood-free sections of myocardial tissue were fixed in bovine's fluid (picric acid:formalin:acetic acid [75:25:5]) and were washed thoroughly in repeated changes of $70 \%$ alcohol. The dehydrated sections were treated with toluene:xylene (50:50) and embedded in paraffin wax. The embedded cardiac tissue was serially cut in horizontal plane on a Leitz microtome to obtain $5 \mu \mathrm{m}$ to $15 \mu \mathrm{m}$ thick sections, which were mounted on glass slides with egg albumin in glycerin solution $(50 \% \mathrm{v} / \mathrm{v})$. They were then stained with $10 \%$ hematoxylin for $3 \mathrm{~min}$ to $5 \mathrm{~min}$ followed by treatment with $10 \%$ eosin for $2 \mathrm{~min}$. The sections were viewed under $40 \times$ magnification.

Phytochemical analysis

\section{RESULTS}

The extracts of $\mathrm{C}$ oxycantha was analyzed for total phenolic and total flavonoids content, and antioxidant potential. The total phenolic and total flavonoids content of C oxycantha were $75.2 \mathrm{mg}$ Gallic acid equivalents and $76 \mathrm{mg}$ Rutin equivalents per gram dry weight, respectively (Table 1).

The in vitro evaluation of antioxidant activity of $\mathrm{C}$ oxycantha was performed using the DPPH (1, 1-Diphenyl-2-picrylhydrazyl) assay. The free-radical scavenging activity of C oxycantha was $62.04 \%$, as reported in Table 1. In HPTLC analysis, comparison of the spectral characteristic of the peaks of standards (ursolic acid) and sample revealed the identity of standards (ursolic acid) in the $\mathrm{C}$ oxycantha extract. The $\mathrm{C}$ oxycantha extract was able to resolve the ursolic acid in the developing solvent system by using mobile phase, which produced good separation, with $R_{f}$ value 0.90 . The standard ursolic acid $R_{f}$ value was 0.91 . The content of ursolic acid in the investigative $\mathrm{C}$ oxycantha extract was quantitatively analyzed by linear regression and was found to be $0.3 \mu \mathrm{g} / \mathrm{mL}$ (Figures 1 and 2).

Effect of C oxycantha on cardiac biomarkers

A statistically significant (ie, $\mathrm{P}<0.05$ ) increase in heart weight:body weight ratio was found in ISO-treated rats compared with the control group. $\mathrm{C}$ oxycantha was found to prevent significant increase in this ratio (Table 2). Serum $\mathrm{cTnI}$ and CK-MB are crucial biomarkers for myocardial damage, which were found to be significantly
TABLE 4

Effect of Crataegus oxycantha on serum SGOT, SGPT and uric acid

\begin{tabular}{llll}
\hline Group & SGOT, IU/L & SGPT, IU/L & Uric acid, $\mathrm{mg} / \mathrm{dL}$ \\
\hline Control & $157.8 \pm 18.94$ & $84.33 \pm 14.22$ & $2.393 \pm 0.684$ \\
$\begin{array}{l}\text { Control + C oxycantha } 50 \mathrm{mg} / \mathrm{kg} \\
\text { body weight orally }\end{array}$ & $159.0 \pm 8.16$ & $82.67 \pm 6.64$ & $2.143 \pm 0.455$ \\
ISO $(100 \mathrm{mg} / \mathrm{kg})$ & & & \\
ISO $(100 \mathrm{mg} / \mathrm{kg}+$ C oxycantha & $204.6 \pm 10.37^{\dagger}$ & $148.8 \pm 7.87^{\dagger}$ & $3.180 \pm 0.456^{\dagger}$ \\
$25 \mathrm{mg} / \mathrm{kg}$ body weight orally) & & & \\
ISO $(100 \mathrm{mg} / \mathrm{kg}+$ C oxycantha & $187.7 \pm 9.73^{\dagger}$ & $125.4 \pm 6.80^{\dagger \ddagger}$ & $2.362 \pm 0.401^{\dagger}$ \\
$50 \mathrm{mg} / \mathrm{kg}$ body weight orally) & & & \\
\hline
\end{tabular}

Data presented as mean $\pm S D$. *Significantly different from control $(P<0.05)$;

${ }^{\dagger}$ Significantly different from isoproteronol (ISO)-treated group $(P<0.05)$; ${ }^{\ddagger}$ Significantly different from C oxycantha $25 \mathrm{mg} / \mathrm{kg}(P<0.05)$. SGOT Serum glutamate oxaloacetate transaminase; SGPT Serum glutamate pyruvate transaminase

\section{TABLE 5}

Effect of Crataegus oxycantha on serum total cholesterol, triglycerides and high-density lipoprotein (HDL) cholesterol

\begin{tabular}{lccc}
\hline & \multicolumn{3}{c}{ Serum concentrations, mmol/L } \\
\cline { 2 - 4 } Groups & $\begin{array}{c}\text { Total } \\
\text { cholesterol }\end{array}$ & Triglycerides & $\begin{array}{c}\text { HDL } \\
\text { cholesterol }\end{array}$ \\
\hline Control & $1.45 \pm 0.14$ & $0.43 \pm 0.05$ & $0.65 \pm 0.10$ \\
Control + C oxycantha & $1.37 \pm 0.18$ & $0.46 \pm 0.06$ & $0.62 \pm 0.17$ \\
$\quad(50 \mathrm{mg} / \mathrm{kg}$ body weight orally) & & & \\
ISO $(100 \mathrm{mg} / \mathrm{kg})$ & $2.03 \pm 0.18^{\star}$ & $0.67 \pm 0.04^{*}$ & $0.70 \pm 0.10$ \\
ISO $(100 \mathrm{mg} / \mathrm{kg}+$ C oxycantha & $1.64 \pm 0.15^{\dagger}$ & $0.53 \pm 0.05^{\dagger}$ & $0.61 \pm 0.14$ \\
$25 \mathrm{mg} / \mathrm{kg}$ body weight orally) & & & \\
ISO $(100 \mathrm{mg} / \mathrm{kg}+$ C oxycantha & $1.31 \pm 0.15^{\dagger \ddagger}$ & $0.41 \pm 0.04^{\dagger \ddagger}$ & $0.56 \pm 1.13$ \\
$50 \mathrm{mg} / \mathrm{kg}$ body weight orally) & & &
\end{tabular}

Data presented as mean $\pm S D$. *Significantly different from control $(P<0.05)$; ${ }^{\dagger}$ Significantly different from isoproterenol (ISO)-treated group $(P<0.05)$; ¥Significantly different from C oxycantha $25 \mathrm{mg} / \mathrm{kg}(P<0.05)$

increased $(\mathrm{P}<0.05)$ after ISO treatment in rats compared with control. Administration of $\mathrm{C}$ oxycantha produced significant reduction $(\mathrm{P}<0.05)$ in serum $\mathrm{cTnI}, \mathrm{CK}-\mathrm{MB}$ and $\mathrm{LDH}$ levels compared with the ISO-treated group, thus exhibiting prevention of cardiac damage produced by myocardial ischemia. The reduction in CK-MB level produced by $\mathrm{C}$ oxycantha was dose dependent (Table 3 ).

Subcutaneous administration of ISO produced significant $(\mathrm{P}<0.05)$ increase in serum SGOT, SGPT and uric acid levels in rats compared with control. $\mathrm{C}$ oxycantha (in both the doses) significantly $(\mathrm{P}<0.05)$ prevented the increase in serum level of these parameters compared with the ISO group (Table 4).

Effect of C oxycantha on lipid parameters

Serum cholesterol and triglyceride level in ISO-treated rats were significantly $(\mathrm{P}<0.05)$ increased compared with control. After treatment with $\mathrm{C}$ oxycantha at both the doses, there were significant reductions $(\mathrm{P}<0.05)$ in cholesterol and triglyceride level in a dose-dependent manner. However, there were no significant changes observed in HDL cholesterol level in ISO-treated animals as well as in C oxycanthatreated groups (Table 5).

Significant $(\mathrm{P}<0.05)$ increase in serum LDL cholesterol and very low LDL (VLDL) cholesterol level were found in ISO-treated rats compared with control. Treatment with $\mathrm{C}$ oxycantha at both the doses significantly $(\mathrm{P}<0.05)$ prevented increases in serum LDL cholesterol and VLDL cholesterol level compared with ISO and the effect was also significantly dose dependent. There was also a significant $(\mathrm{P}<0.05)$ increase in the atherogenic index in ISO-treated rats, which was significantly $(\mathrm{P}<0.05)$ prevented by higher dose of $\mathrm{C}$ oxycantha; however, the result was not significant at the lower dose. $\mathrm{C}$ oxycantha extract produced a significant $(\mathrm{P}<0.05)$ increase in fecal cholesterol 


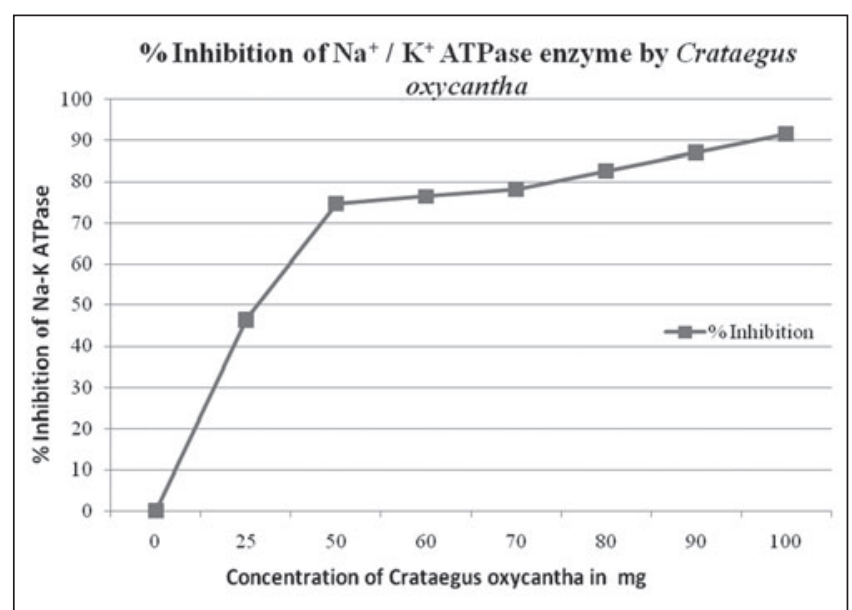

Figure 3) Evaluation of $\mathrm{Na} / \mathrm{K}+$ ATPase enzyme inhibition activity of Crataegus oxycantha

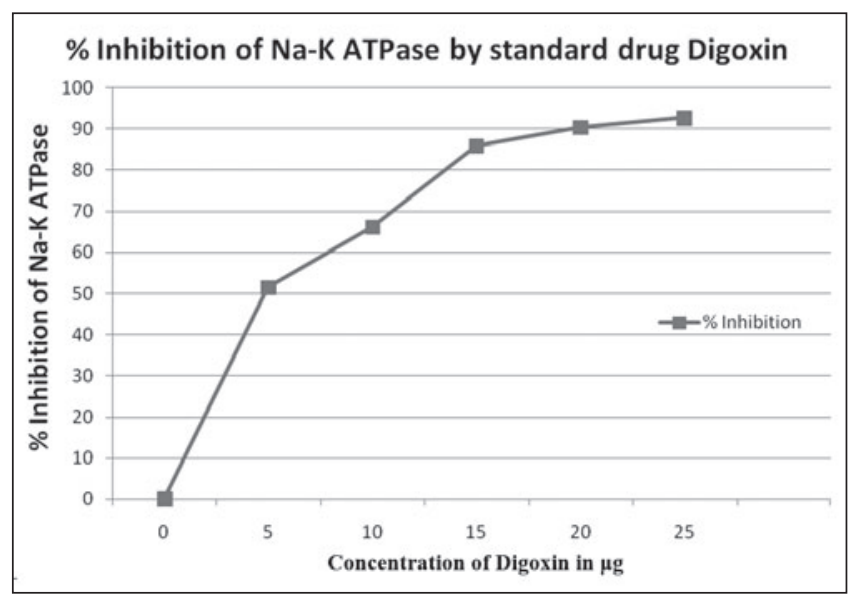

Figure 4) $\mathrm{Na}+\mathrm{K}+$ ATPase enzyme inhibition activity of digoxin

excretion. The differences in cholesterol excretion were significant $(\mathrm{P}<0.05)$ at two test doses of $\mathrm{C}$ oxycantha extract. Positive changes in the above parameters reflect prevention of atherogenesis (Table 6).

Effect of C oxycantha oxidative stress in myocardial tissue Administration of ISO in rats produced significant $(\mathrm{P}<0.05)$ increases in malondialdehyde levels, a product of LPO in heart homogenate compared with control. Pretreatment with $\mathrm{C}$ oxycantha at both doses was found to prevent significant increases in malondialdehyde levels $(\mathrm{P}<0.05)$. There was significant $(\mathrm{P}<0.05)$ reduction in $\mathrm{SOD}$, catalase and GSH levels in heart homogenates of ISO-treated rats, which were significantly $(\mathrm{P}<0.05)$ prevented after treatment at both the doses of $\mathrm{C}$ oxycantha extract as reported in Table 7 .

\section{Effect of $\mathrm{C}$ oxycantha on $\mathrm{Na}^{+} / \mathrm{K}^{+}$ATPase enzyme in myocardial} tissue

C oxycantha has been reported to possess positive inotropic properties, which may be due to inhibition of $\mathrm{Na}^{+} / \mathrm{K}^{+}$ATPase enzyme. The result suggested that $\mathrm{C}$ oxycantha produced significant dose-dependent inhibition of $\mathrm{Na}^{+} / \mathrm{K}^{+}$ATPase enzyme present in heart homogenates of rats (Figure 3).

Standard drug digoxin also produced significant dose-dependent reduction in myocardial $\mathrm{Na}^{+} / \mathrm{K}^{+}$ATPase enzyme activity in heart homogenates of rats; however, compared with $\mathrm{C}$ oxycantha (in milligram concentration), digoxin produced a nearly similar extent of $\mathrm{Na}^{+} /$ $\mathrm{K}^{+}$ATPase enzyme inhibition in microgram $(\mu \mathrm{g})$ concentration (Figure 4).

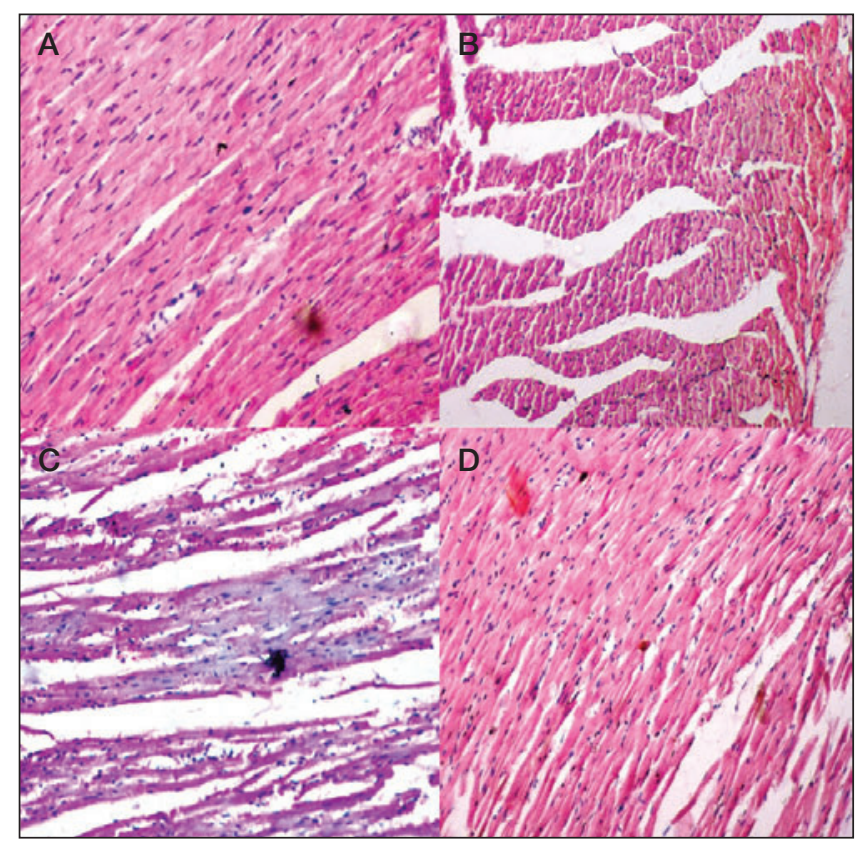

Figure 5) Representative slides of hematoxylin and eosin-stained microscopic sections of rat cardiac tissue. A Normal control. B Disease control (injected with isoprenaline, subcutaneous [sc]). C Pretreated with Crataegus oxycantha (25 mg/kg orally) and isoprenaline sc. D Pretreated with C oxycantha (50 mg/kg orally) and isoprenaline sc

\section{Histopathology}

Histological sections of cardiac tissue of normal control rats exhibited normal size muscle fibres with plump nuclei and normal cytoarchitecture (Figure 5A). The ISO-treated rats elicited severe cardiac damage, as evidenced by pathological changes in the architecture of the heart. There was loss of cellular architecture with necrotic changes in cardiac tissue. Intercellular edema, increased waviness and inflammation were observed in cardiac tissue of ISO-treated rats (Figure 5B). The myocardial section of rats pretreated with the lower dose of $\mathrm{C}$ oxycantha ( $25 \mathrm{mg} / \mathrm{kg}$ ) exhibited persistent damage with thinned-out fibres, diffuse infiltration of leukocytes with prominent hyperchromasia and increased intercellular space suggestive of edema (Figure 5C), while the sections of rat hearts pretreated with the higher dose of $\mathrm{C}$ oxycantha $(50 \mathrm{mg} / \mathrm{kg})$ elicited almost complete prevention of myocardial necrosis. Plump myocardial fibres with mild disruption, no leukocyte infiltrates and no edema were observed in these sections (Figure 5D).

\section{DISCUSSION}

Antioxidants, such as flavonoids, polyphenols, tannins and anthocyanidins, and certain vitamins are gaining more importance in the prevention of chronic conditions such as cardiovascular disease, diabetes and atherosclerosis. It was also reported that $\mathrm{C}$ oxycantha possess potent antioxidants such as vitamin $C$, many flavanoids, oligomeric procyanidin-epicatechol, cardiotonic amines, tannins, saponins and triterpene acid (11). In the present study, C oxycantha extract showed the presence of rich content of total flavonoids and phenolic compounds, which may be responsible for their strong antioxidant efficacy. The in vitro DPPH (1,1-diphenyl-2-picrylhydrazyl) assay is preferably and widely used to assess free-radical scavenging activity of antioxidant vitamins and plant extracts (12). In our investigation, the DPPH assay of $\mathrm{C}$ oxycantha produced significant free radical scavenging activity $(62.04 \%)$ by reducing the stable DPPH radicals, which may be attributed to rich content of total phenolics and flavanoids present in the extract.

The HPTLC method is the most precise and reliable method for qualitative and quantitative estimation of different phytoconstituents present in plant extracts. In our qualitative analysis, the HPTLC 
TABLE 6

Effect of Crataegus oxycantha on serum low-density lipoprotein (LDL) and very low-density LDLD (VLDL) cholesterol, atherogenic index (ratio of LDL to high-density lipoprotein) and fecal cholesterol

\begin{tabular}{|c|c|c|c|c|}
\hline \multirow[b]{2}{*}{ Group } & \multicolumn{2}{|c|}{ Cholesterol, $\mathrm{mmol} / \mathrm{L}$} & \multirow[b]{2}{*}{ Atherogenic index } & \multirow{2}{*}{$\begin{array}{c}\text { Fecal } \\
\text { cholesterol, } \mathrm{mmol} / \mathrm{L}\end{array}$} \\
\hline & LDL & VLDL & & \\
\hline Control & $0.56 \pm 0.16$ & $0.24 \pm 0.01$ & $0.89 \pm 0.14$ & $0.52 \pm 0.06$ \\
\hline Control $+C$ oxycantha $50 \mathrm{mg} / \mathrm{kg}$ body weight orally & $0.54 \pm 0.06$ & $0.20 \pm 0.01$ & $0.94 \pm 0.12$ & $0.66 \pm 0.09$ \\
\hline ISO (100 mg/kg + C oxycantha $25 \mathrm{mg} / \mathrm{kg}$ body weight orally & $0.78 \pm 0.05^{\dagger}$ & $0.24 \pm 0.01^{\dagger}$ & $1.32 \pm 0.13$ & $0.89 \pm 0.09^{\dagger}$ \\
\hline ISO (100 mg/kg + C oxycantha $50 \mathrm{mg} / \mathrm{kg}$ body weight orally & $0.52 \pm 0.06^{\dagger \ddagger}$ & $0.19 \pm 0.01^{\dagger \ddagger}$ & $0.94 \pm 0.10^{\dagger}$ & $1.10 \pm 0.09^{\dagger \ddagger}$ \\
\hline
\end{tabular}

Data presented as mean $\pm S D$. * Significantly different from control $(p<0.05) ;{ }^{\dagger}$ Significantly different from isoproterenol $\left(\right.$ ISO)-treated group $(P<0.05) ;{ }^{\ddagger}$ Significantly different from $\mathrm{C}$ oxycantha $25 \mathrm{mg} / \mathrm{kg}(P<0.05)$

\section{TABLE 7}

Effect of Crataegus oxycantha on lipid peroxidation, superoxide dismutase, catalase and reduced glutathione (GSH) levels

\begin{tabular}{|c|c|c|c|c|}
\hline Group & Lipid peroxidation* & Superoxide dismutase $^{\dagger}$ & Catalase $^{\ddagger}$ & Reduced GSH§ \\
\hline Control & $17.70 \pm 0.98$ & $36.88 \pm 2.16$ & $65.38 \pm 2.56$ & $98.71 \pm 2.58$ \\
\hline Control $+C$ oxycantha $50 \mathrm{mg} / \mathrm{kg}$ body weight orally & $17.90 \pm 2.57$ & $35.99 \pm 4.04$ & $65.89 \pm 3.29$ & $99.62 \pm 3.79$ \\
\hline ISO (100 mg/kg) & $39.78 \pm 1.45^{\Uparrow}$ & $24.25 \pm 2.04^{\top}$ & $42.05 \pm 2.15^{\Uparrow}$ & $75.05 \pm 2.74^{\pi}$ \\
\hline ISO (100 mg/kg + C oxycantha 25 mg/kg body weight orally) & $27.58 \pm 2.28^{\star \star}$ & $33.44 \pm 2.79^{\star \star}$ & $56.27 \pm 5.11^{\star *}$ & $86.04 \pm 5.47^{\star *}$ \\
\hline ISO (100 mg/kg + C oxycantha 50 mg/kg body weight orally) & $19.17 \pm 2.98^{\star \star \dagger}$ & $36.65 \pm 3.38^{\star *}$ & $66.65 \pm 3.73^{\star \star \dagger \dagger}$ & $100.0 \pm 3.83^{\star *}+\dagger$ \\
\hline
\end{tabular}

Data presented as mean $\pm \mathrm{SD}$. ${ }^{\star}$ Expressed as $\mathrm{nM}$ malondialdehyde/g tissue; ${ }^{\dagger}$ Expressed as units/g tissue; ${ }^{\ddagger}$ Expressed as $\mu \mathrm{mol} \mathrm{H}_{2} \mathrm{O}_{2}$ Consumed/min/g tissue; ${ }^{\S}$ Expressed as $\mu \mathrm{g} \mathrm{GSH/g} \mathrm{tissue;} \mathrm{"Significantly} \mathrm{different} \mathrm{from} \mathrm{control}(P<0.05)$; **Significantly different from isoproteronol (ISO)-treated group ( $\left.P<0.05\right)$; ${ }^{+}$Significantly different from C oxycantha $25 \mathrm{mg} / \mathrm{kg}(P<0.05)$

chromatogram exhibited clearly resolution peak of terpenoid-ursolic acid present in investigative C oxycantha extract. Quantitative analysis using HPTLC also showed that rich amounts of ursolic acid is present in $\mathrm{C}$ oxycantha extract.

The rat model of ISO-induced myocardial necrosis, among many well known models, has often been used to evaluate several cardiac dysfunctions (13). The pathophysiological changes following ISO administration are comparable with those occurring in human myocardial alterations (14). Milei et al (15) reported that the myocardial lesions in rats induced by ISO may be due to action on the sarcolemma, stimulation of adenylate cyclase, activation of $\mathrm{Na}^{+}$and $\mathrm{Ca}^{2+}$ channel, increase of calcium inflow and energy consumption leading to myocardial cellular death. In this context, Dhalla et al (16) reported that excessive catecholamine may affect transport mechanism of calcium primarily via oxidation reactions involving free radical-mediated damage and, hence, antioxidants may be indicated for stress induced heart disease.

Increased heart weight and heart/body weight ratio indicates cardiac hypertrophy, which may be due to ventricular stiffness, increased water content and extensive necrosis of cardiac muscle followed by invasion of damaged tissue by inflammatory cells $(17,18)$. In the present study, there was also a significant increase in heart weight and heart/body weight ratio in ISO-treated rats compared with control. Pretreatment with $\mathrm{C}$ oxycantha produced significant prevention of increase in the heart weight and heart/body weight ratio in ISOtreated rats. In this context, Choudhary et al (19) reported that increased generation of reactive oxygen species (ROS) and oxidative stress is implicated in catecholamine-induced myocardial damage and the progression of cardiac hypertrophy. In the present study, the antioxidant nature of $\mathrm{C}$ oxycantha may have been responsible for prevention of myocardial damage, decrease in heart weight/body weight ratio and subsequent prevention of cardiac hypertrophy.

Elevated serum troponin levels predict the risk of both cardiac death and subsequent infarction. It was reported that increased serum levels of cTnI was associated with the development of cardiac lesions in acute models of cardiac injury $(20,21)$. In the present study, ISO-treated rats showed significant increase in serum cTnI level, which may be due to myocardial tissue damage produced by ISO. In our investigation, pretreatment with $\mathrm{C}$ oxycantha significantly prevented the increase in serum cTnI level in ISO-treated rats.
The assay of activity of CK-MB isoenzyme in serum is a specific and useful index in the diagnosis of myocardial damage and subsequent infarction because of the marked abundance of this enzyme in heart and virtual absence from most of other tissues (22). The presence of CK-MB and $\mathrm{LDH}$ in heart tissue homogenate indicates myocardial integrity, while, their increased serum level after the release from heart tissue signifies myocardial injury (23). In the present study, serum CK-MB level was significantly increased in ISO-treated rats, which suggests the myocardial injury and loss of myocardial membrane integrity. Pretreatment with $\mathrm{C}$ oxycantha produced significant reduction in serum CK-MB level in ISO-treated rats.

Witteveen et al (24) reported that LDH, serum glutamate oxaloacetate transaminase (SGOT) and serum glutamate pyruvate transaminase (SGPT) enzymes levels in serum are supportive diagnostic marker of myocardial damage. When myocardial cells are damaged or destroyed due to the deficiency of oxygen supply or glucose, the cell membrane becomes permeable or may rupture and results in the leakage of these enzymes into serum (15). In our investigation, we also found a significant increase in serum levels of LDH, SGOT and SGPT in ISO-treated rats, which were decreased to significant level in $\mathrm{C}$ oxycantha pretreated rats. The reduction in serum level of all above cardiac biomarkers indicates prevention of myocardial damage and maintenance of myocardial cell integrity by $\mathrm{C}$ oxycantha.

Weir et al (25) reported that serum uric acid is considered to be a risk factor in the development of myocardial infarction. In ischemic condition, tissue becomes hypoxic and, consequently, ATP depletion occurs, which causes accumulation of hypoxanthine. Xanthine oxidase catalyses the conversion of hypoxanthine to xanthine, uric acid and superoxide. This may be the one of the reasons for the elevated level of serum uric acid in ISO-treated rats in our investigation. Along with uric acid, generation of superoxide radicals leads to further increase in oxidative stress, which may be additive factor in myocardial necrosis produced by ISO. Swaminathan et al (26) revealed that C oxycantha significantly inhibited the activity of xanthine oxidase. In our study, $\mathrm{C}$ oxycantha-pretreated rats produced significant decrease in serum uric acid level after ISO administration, which may be due to inhibition of xanthine oxidase.

Sushamakumari et al (27) reported that ISO promotes tissue lipolysis. Enhancement in lipolysis and subsequent elevation of plasma free fatty acid (FFA) level may lead to an increased hepatic triglyceride 
synthesis resulting in elevated plasma triglyceride and cholesterol level. Manjula et al (28) reported the elevated level of cholesterol and triglyceride in ISO-induced myocardial damaged rats, which can be correlated with previous findings. It was reported earlier that hyperlipidemia is a prominent feature of ISO-induced cardiovascular disturbances $(29,30)$. In the present study, serum cholesterol, triglyceride, LDL cholesterol, VLDL cholesterol and atherogenic index were significantly increased ISO-treated animals. Thus, our results can be clearly correlated with previous findings.

An excess of lipids in the circulation is considered to accelerate the development of atherosclerosis and is a risk factor for myocardial infarction. A strong positive correlation was well documented between the risk for developing ischemic heart disease and increased serum LDL cholesterol level. In the present investigation, C oxycantha produced significant decrease in serum levels of total cholesterol, triglyceride, LDL cholesterol and atherogenic index. Higher LDL to HDL ratio and atherogenic index are indicators of proatherosclerotic event. There was significant reduction in LDL to HDL ratio (atherogenic index) produced by $\mathrm{C}$ oxycantha in ISO-treated rats. This may be due to significant decrease in LDL cholesterol level by $\mathrm{C}$ oxycantha. Yuguang et al (31) reported that $\mathrm{C}$ oxycantha prevents cholesterol absorption by inhibiting enzyme Acyl CoA:cholesterol acetyl transferase (ACAT), which may be attributed to triterpenic acid-like ursolic acid present in the extract. Our HPTLC analysis also showed rich amounts of ursolic acid present in $\mathrm{C}$ oxycantha, which can be correlated with the above possible mechanism of its hypolipidemic activity. The unabsorbed cholesterol may be reflected in fecal matter. In our investigation, a dose-dependent significant increase in fecal cholesterol content was observed in ISO-treated rats pretreated with $\mathrm{C}$ oxycantha. Our results suggest that increased fecal cholesterol excretion may be attributed to inhibition of ACAT enzyme by virtue of presence of ursolic acid in C oxycantha.

It was demonstrated that catecholamine-like ISO increases generation of ROS via oxidation, which may lead to myocardial necrosis $(32,33)$. LPO is one of the main manifestations of oxidative damage initiated by ROS and can be linked to the altered membrane structure and leakage of enzymes (34). In our study, a significant increase in LPO in terms of malondialdehyde was observed in ISO-treated rats, which suggests generation of oxidative stress by ISO and subsequent damage to myocardial membrane leading to release of enzymes, such as cTnI, CK-MB, LDH, SGOT and SGPT, into the serum. It was reported that $\mathrm{C}$ oxycantha is effective in quenching free radicals and inhibit LPO due to rich content of phenols and flavonoids $(35,36)$. In our investigation, LPO was significantly prevented by pretreatment with $\mathrm{C}$ oxycantha in ISO-treated animals, which may be attributed to the presence of flavonoids and phenols in the extract.

Asdaq et al (23) reported that ISO-induced myocardial necrosis is associated with decreases in endogenous antioxidants such as SOD, catalase and GSH, resulting in myocardial damage. The present investigation also showed similar results. Subcutaneous ISO administration produced significant decrease in SOD, catalase and reduced GSH in myocardial tissue, which were restored to normal levels after pretreatment with $\mathrm{C}$ oxycantha. The increase in endogenous antioxidant activities in heart homogenate of rats pretreated with $\mathrm{C}$ oxycantha is an indication for myocardial structural integrity and protection to the myocardium, which may be responsible for cardioprotection.

Schwinger et al (37) demonstrated that Crataegus extract increased the force of contraction in left ventricular papillary muscle strips through a cAMP independent mechanism. It was suggested that Crataegus's positive inotropic effect may also be due to inhibition of membrane-bound myocardial $\mathrm{Na}^{+} / \mathrm{K}^{+}$ATPase, which maintains cardiac resting potential (38). It is also reported to have increased exercise tolerance during the early stage of congestive cardiac failure. The mechanism for cardiotonic activity of $\mathrm{C}$ oxycantha was proposed that ursolic acid of $\mathrm{C}$ oxycantha may interact with the digitaloid binding site of $\mathrm{Na}^{+}-\mathrm{K}^{+}$ATPase enzyme and responsible for positive inotropic effect of $\mathrm{C}$ oxycantha (38). Our investigation demonstrated that $\mathrm{C}$ oxycantha significantly inhibits $\mathrm{Na}^{+}-\mathrm{K}^{+}$ATPase enzyme present in heart homogenate, which may be attributed to ursolic acid present in the extract. Our results also suggest that $\mathrm{Na}^{+}-\mathrm{K}^{+}$ATPase enzyme inhibiting activity of $\mathrm{C}$ oxycantha is comparable with the standard cardiotonic drug digoxin; however, in our investigation, digoxin (being a pure compound) was required in significantly lower amounts to produce inhibition of $\mathrm{Na}^{+}-\mathrm{K}^{+}$ATPase compared with $\mathrm{C}$ oxycantha. On the other hand, Joseph et al (39) reported that digoxin and other cardioprotective drugs shorten the refractory period of the myocardium leading to increased risk for arrhythmias, while Crataegus prolongs the refractory phase, reducing the risk for arrhythmias. Blesken (40) suggested that Crataegus simultaneously exerts cardiotropic and vasodilatory action and, hence, can be safely and effectively used as a cardiotonic. The above findings suggest that $\mathrm{C}$ oxycantha may be safer and better option as a cardiotonic; however, further research is required to establish this. From our results and previous findings, we propose that the cardiotonic effect of $\mathrm{C}$ oxycantha may be due to its ursolic acid content binding to digitalis site on the $\mathrm{Na}^{+}-\mathrm{K}^{+}$ATPase enzyme. The HPTLC analysis of our $\mathrm{C}$ oxycantha extract exhibited the presence of ursolic acid. Thus, the cardiotonic effect of $\mathrm{C}$ oxycantha may be due to ursolic acid binding to digitaloid site and may be responsible for producing actions similar to digoxin.

\section{CONCLUSION}

Our data suggest that $\mathrm{C}$ oxycantha offers protection to the myocardium, as evidenced by maintaining serum cTn-I, CK-MB and other cardiac marker enzymes to nearly normal levels in ISO-treated rats. The histopathology of myocardial tissue further confirms the cardioprotective activity. The possible mechanism of cardiotonic activity of $\mathrm{C}$ oxycantha appears to be inhibition of myocardial $\mathrm{Na}^{+}-\mathrm{K}^{+}$ATPase enzyme in isolated rat hearts, which may be attributed to presence of ursolic acid in the extract.

DISCLOSURES: None of the authors have actual or potential conflict of interest to disclose, including financial, personal or other relationships with specific persons or organizations.

\section{REFERENCES}

1. Schmidt U, Kuhn U, Ploch M. Hubner WD. Efficacy of the hawthorn preparation LI 132 in 78 patients with chronic congestive heart failure defined as NYHA functional class II. Phytomed 1994;1:17-24.

2. Taskov M. On the coronary and cardiotonic action of crataemon. Acta Physiol Pharm Bulgarica 1977;3:53-7.

3. Abu Bakar MF, Mohamed M, Rahmat A, Fry J. Phytochemicals and antioxidant activity of different parts of bambangan (Mangifera pajang) and tarap (Artocarpus odoatissimus). Food chemistry 2009;113:479-83.

4. Mensor LI, Menezes FS, Leitao GG, et al. Screening of Brazilian plants extracts for antioxidants activity by the use of DPPH free radical method. Phytother Res 2001;15:127-30.

5. Folch J, Lees M, Stanley Sloane GH. A simple method for the isolation and purification of total lipids from animal tissues. J Biol Chem 1957;226:497-509.

6. Slater RF, Sawyer BC. The stimulatory effects of carbon tetrachloride and other halogenoalkanes or peroxidative reactions in rat liver fractions in vitro. Biochem J 1971;123:805-14.

7. Mishra HP, Fridovich I. The role of superoxide anion in the autooxidation of epinephrine and a simple assay for superoxide dismutase. J Biol Chem 1972;247:3170-5.

8. Moron MS, Depierre JW, Mannervik B. Levels of glutathione, glutathione reductase and glutathione-s-transferase activities in rat lung and liver. Biochimica Biophysica Acta 1979;582:67-78.

9. Hugo EB. Oxidoreductases acting on groups other than $\mathrm{CHOH}$ : Catalase. Methods Enzyml 1984;105:121-5.

10. Bonting SL. Sodium-potassium activated adenosine triphosphatase and cation transport. In: Membranes and Ion Transport, EE Bittar, ed. London: Interscience Publishers, Ltd, 1970;1:257. 
11. Barnes J, Anderson LA, Philipson JD. Herbal Medicines. A guide for health care professionals, 1st edn. London: Pharmaceutical Press Publication, 1996:284-7.

12. Sakanaka S, Tachibana Y, Okada Y. Preparation and antioxidant properties of extracts of Japanese persimmon leaf tea (kakinohacha) Food Chem 2005;89:569-75.

13. Wexler BC. Myocardial infarction in young versus old male rats: Pathophysiologic changes. Am Heart J 1978;96:70-80.

14. Karthikeyan K, Saralabai BR, Devaraj N. Cardioprotective effect of grape seed proanthocyanidins on isoproterenol induced myocardial injury in rats. Int J Cardiol 2007;115:326-33.

15. Milei J, Nunez RG, Rapaport M. Pathogenesis of isoproterenol induced lesions in the rat myocardium. Cardiology 1978;63:139.

16. Dhalla NS, Rupp H, Beamish RE, Bastos ML. Mechanisms of alterations in cardiac membrane calcium transport due to excess catecholamines. Cardiovasc Drug Ther 1996;1:231-8.

17. Nirmala C, Puvanakrishnan R. Effect of curcumin on certain lysosomal hydrolases in isoproterenol induced myocardial infarction in rats. Biochem. Pharmacol 1996;51:47-51.

18. Weber KT, Brilla CG. Pathological hypertrophy and cardiac interstium: Fibrosis and rennin angiotensin aldosterone system. Circulation 1991;83:1849-65.

19. Choudhary R, Mishra KP, Subramanyam C. Prevention of isoproterenol induced cardiac hypertrophy by eugenol, an antioxidant. Indian J Clin Biochem 2006;21:107-13.

20. York M, Scudamore C, Brady S, et al. Characterization of troponin responses in isoproterenol induced cardiac injury in the Hanover Wistar rat. Toxicol Pathol 2007;35:606.

21. O'Brien, Smith PJ, Knechtel EC, et al. Cardiac troponin I is a sensitive, specific biomarker of cardiac injury in laboratory animals. Lab Anim 2006;40:153-71.

22. Rajadurai M, Stanely M. Preventive effect of naringin on cardiac markers, electrocardiographic patterns and lysosomal hydrolases in normal and isoproterenol induced myocardial infarction in Wistar rats. Toxicology 2007;230:178-88.

23. Asdaq SMB, Inamdar MN, Asad M, Nanjundan PK. Interaction of propranolol with garlic in isoproterenol induced myocardial infarction in rat. J Pharmacol Toxicol 2008;3:414-24.

24. Witteveen S, Hemkar HC, Hollar L, Hermens W. Quantitation of infarct size in man by means of plasma enzyme level. Br Heart J 1975;37:795-803.

25. Weir CJ, Muir SW, Walters RM, Lees KR. Serum urate as an independent predictor of poor outcome and future vascular events after acute stroke. Stroke 2003;34:1951-7.

26. Swaminathan JK, Khan M, Mohan IK et al. Cardioprotective properties of Crataegus oxycantha extract against ischemiareperfusion injury. Phytomedicine 2010;10:744-52.

27. Sushamakumari S, Varghese A, Muraleedharan D, Menon VP. Protective action of aspirin in experimental myocardial infarction induced by isoproterenol in rats and its effect on lipid peroxidation. Ind J Exp Biol 1990;28:480-5.
28. Manjula TS, Geetha A, Ramesh TG Shyamala Devi CS. Reversal of changes of myocardial lipids by chronic administration of aspirin in isoproterenol induced myocardial damage in rats. Ind J Physiol Pharmacol 1992;36:47-50.

29. Mathew S, Menon, P, Kurup PA. Changes in myocardial and aortic lipids, lipolytic activity and fecal excretion of sterols and bile acids in isoproterenol-induced myocardial infarction in rats. Ind J Biochem Biophys 1981;18:131-3.

30. Wexler BC, Judd JT, Lutmer RF, Saroff J. Metabolic and histopathological consequences of a fatty liver during the acute stages of myocardial infarction in rats. Br J Exp Pathol 1971;52:565-82.

31. Yuguang L, Mario A, Vermeer, Elke A. Triterpenic acids present in Hawthorn lower plasma cholesterol by inhibiting intestinal ACAT activity in hamsters. Evid Based Complement Alternat Med 2009;2011:1-9.

32. Chaturvedi P. Inhibitory response of Raphanus sativus on lipid peroxidation in albino rats. Evid Based Complement Alternat Med 2008;5:55-9.

33. Shetty S, Udupa S and Udupa L. Evaluation of antioxidant and wound healing effects of alcoholic and aqueous extract of Ocimum sanctum Linn in rats. Evid Based Complement Alternat Med 2008;5:95-101.

34. Yogeeta S, Gnanapragasam A, Subramanian S, Rajakannu S, Sathivel A, Devaki T. Synergistic interactions of ferulic acid with ascorbic acid: Its cardioprotective role during isoproterenol induced myocardial infarction in rats. Mol Cell Biochem2006;283:139-46.

35. Jayalakshmi R, Thirupurasundari CJ, Devaraj NS. Pretreatment with alcoholic extract of Crataegus oxycantha (AEC) activates mitochondrial protection during isoproterenol induced myocardial infarction in rats. Mol and Cell Biochem 2006;292:59-67.

36. Long SR, Carey RA, Crofoot KM, Proteau PJ, Filtz TM. Effect of hawthorn (Crataegus oxycantha) crude extract and chromatographic fractions on multiple activities in a cultured cardiomyocyte assay. Phytomedicine 2006;13:643-50.

37. Schwinger R, Pietsch M, Frank K, Brixius K. Crataegus special extract WS1442 increases force of contraction in human myocardium cAMP independently. J Cardiovasc Pharmacol 2000;35:700-7.

38. Verma SK, Jain V, Verma D, Khamsera R. Crataegus oxycanthaa cardioprotective herb. J Herb Med Toxicol 2007;1:65-71.

39. Joseph G, Zhao Y, Klaus W. Pharmacological action profile of Crataegus extract in comparison to epinephrine, amirinone, milrinone and digoxin in the isolated perfused guinea pig heart. Arzneimittel forschung 1995;45:1261-5.

40. Blesken R. Crataegus in cardiology. Fortschr Med 1992;110:290-2. 